\title{
Equipamientos litúrgicos al aire libre para la JMJ Madrid 2011
}

\section{Liturgical Outdoor Facilities for World Youth Day Madrid 2011}

Ignacio Vicens y Hualde · Universidad Politécnica de Madrid (España)

https://doi.org/10.17979/aarc.2013.3.0.5111

\section{RESUMEN}

Durante la sesión de clausura del III Congreso Internacional de Arquitectura Religiosa Contemporánea, Ignacio Vicens y Hualde relató su experiencia personal en la construcción de las estructuras litúrgicas provisionales que se levantaron en Madrid para acoger la visita de Su Santidad Benedicto XVI durante la Jornada Mundial de la Juventud 2011: un altar en la Plaza de la Cibeles, unos confesionarios portátiles en el Parque del Retiro, y el gran altar en la base aérea de Cuatro Vientos.

\section{ABSTRACT}

During the closing session of the Third International Conference on Contemporary Religious Architecture, Ignacio Vicens y Hualde recounted his personal experience in the construction of the provisional liturgical structures that were erected in Madrid to host the visit of His Holiness Benedict XVI for the Youth World Day 2011: an altar at Plaza de la Cibeles, a portable confessionals in Parque del Retiro, and the great altar at the military airfield of Cuatro Vientos.

\section{PALABRAS CLAVE}

Equipamientos litúrgicos; aire libre; JMJ Madrid 2011; Vicens+Ramos.

\section{KEYWORDS}

Liturgical Outdoor Facilities; World Youth Day Madrid 2011; Vicens+Ramos. 


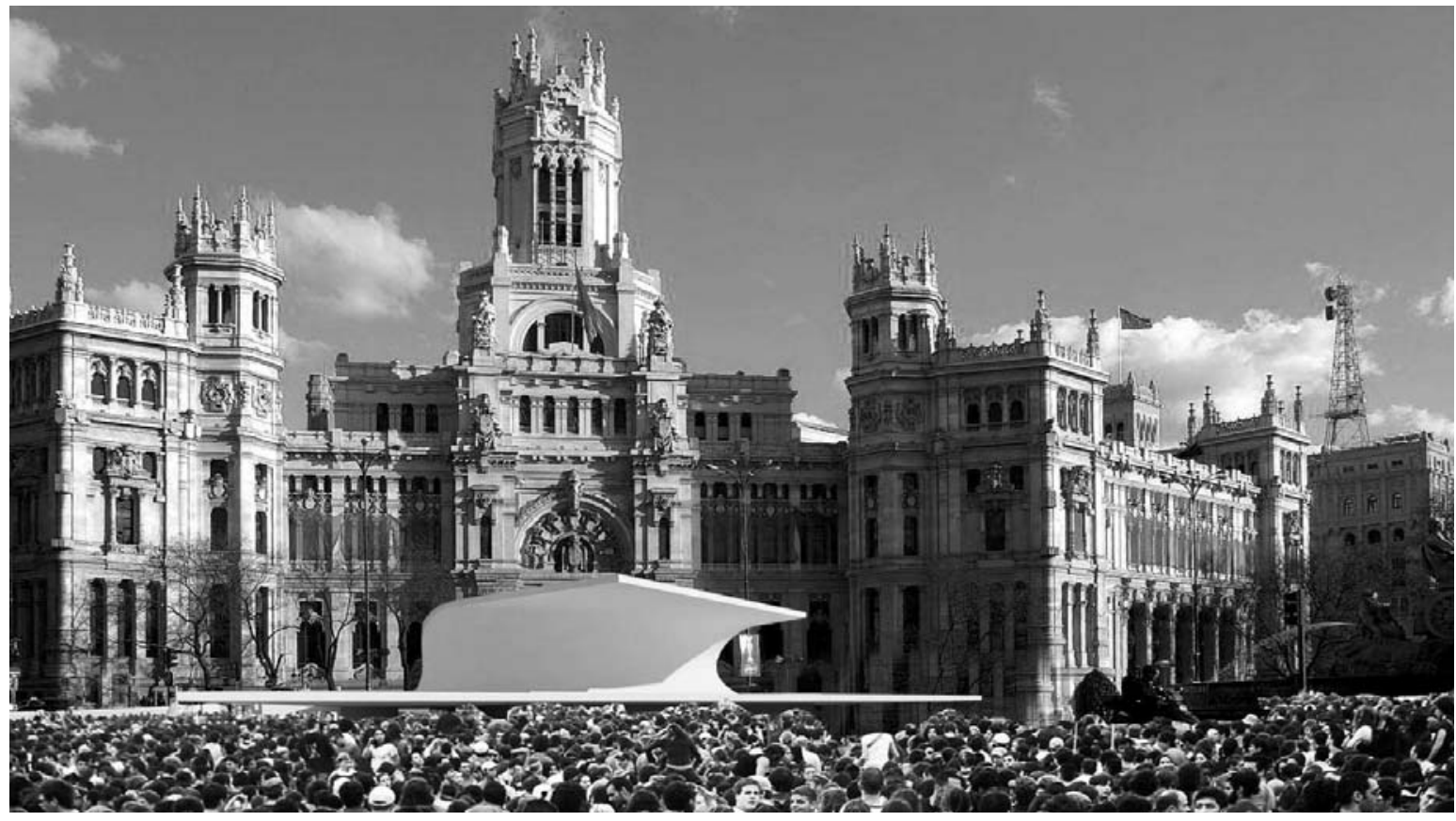

Fig. 01. Vicens+Ramos, Estrado para la Misa de apertura de la JMJ en la plaza de Cibeles; primera versión. Fig. 02. Planta definitiva.

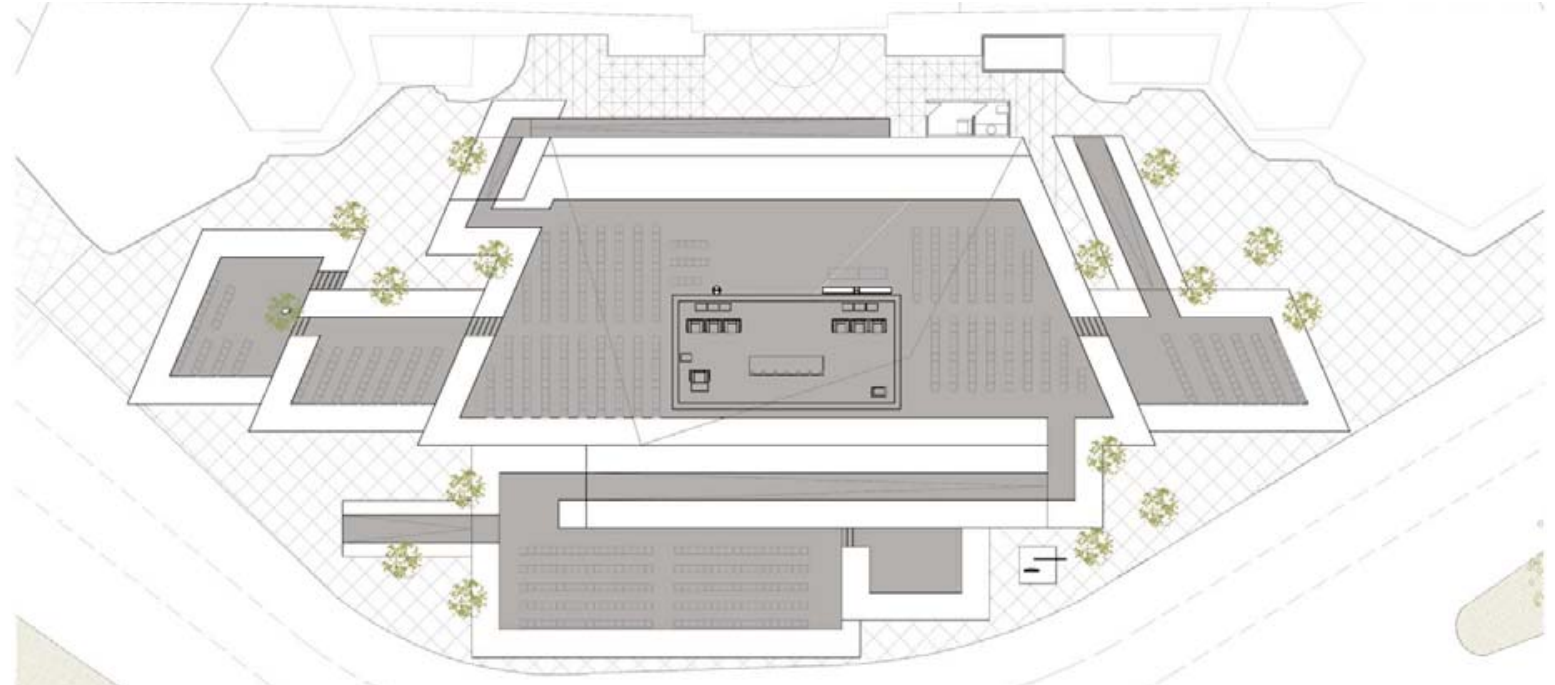




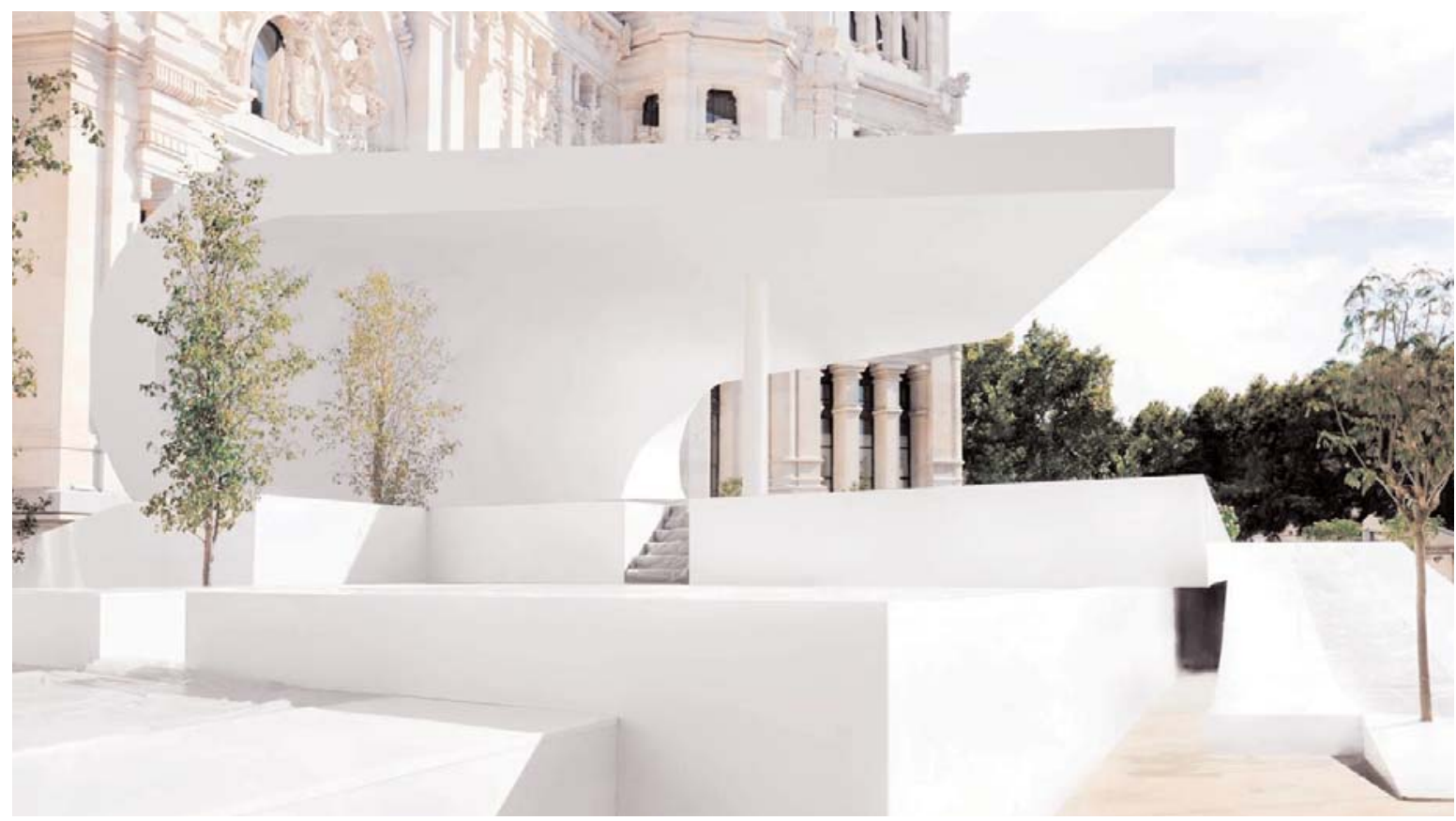

Fig. 03. El estrado construido

Fig. 04. Sección transversal.

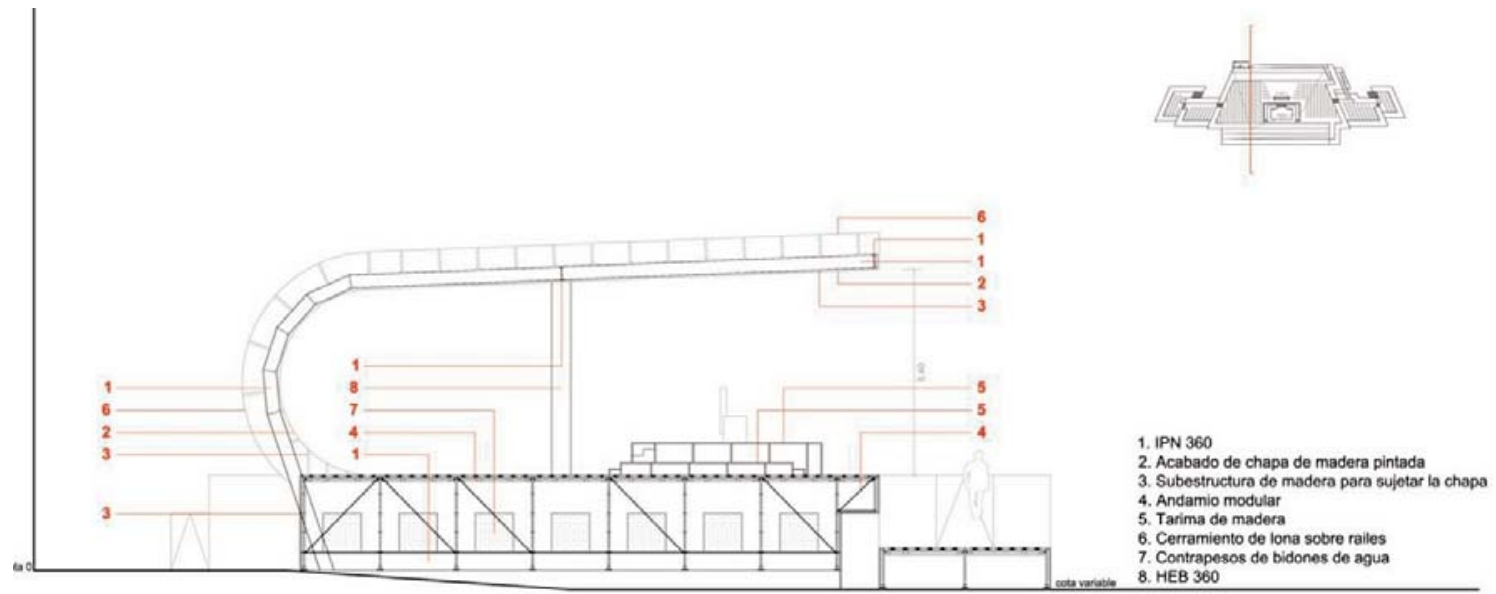




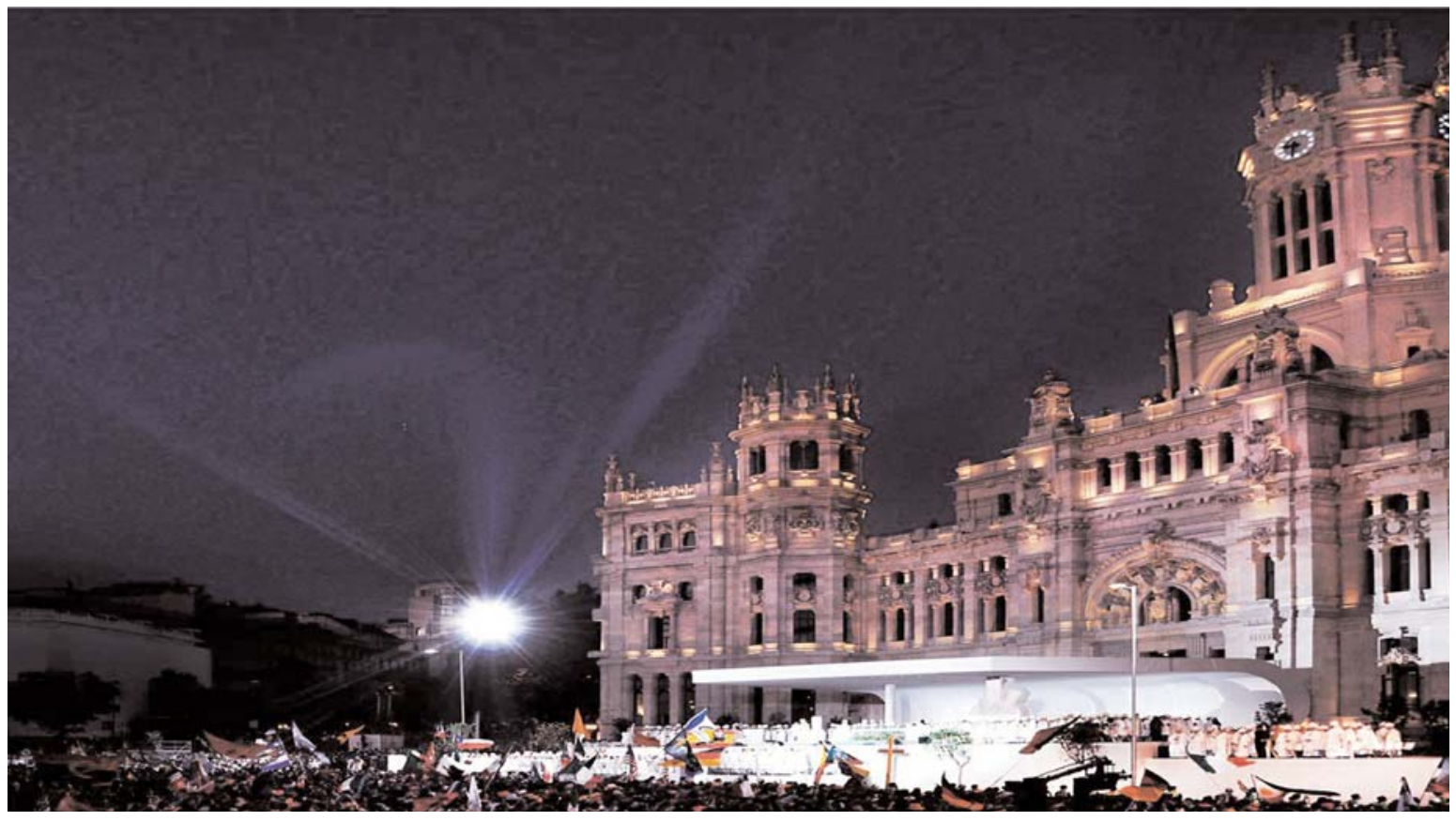

Fig. 05. Misa de apertura de la JMJ en la plaza de Cibeles. Fig. 06. Sede papal.
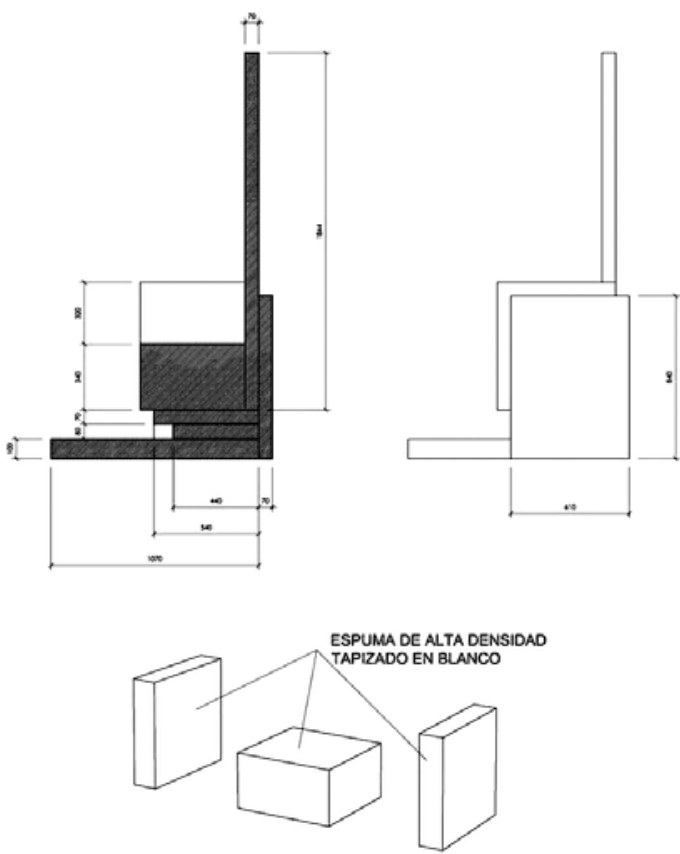
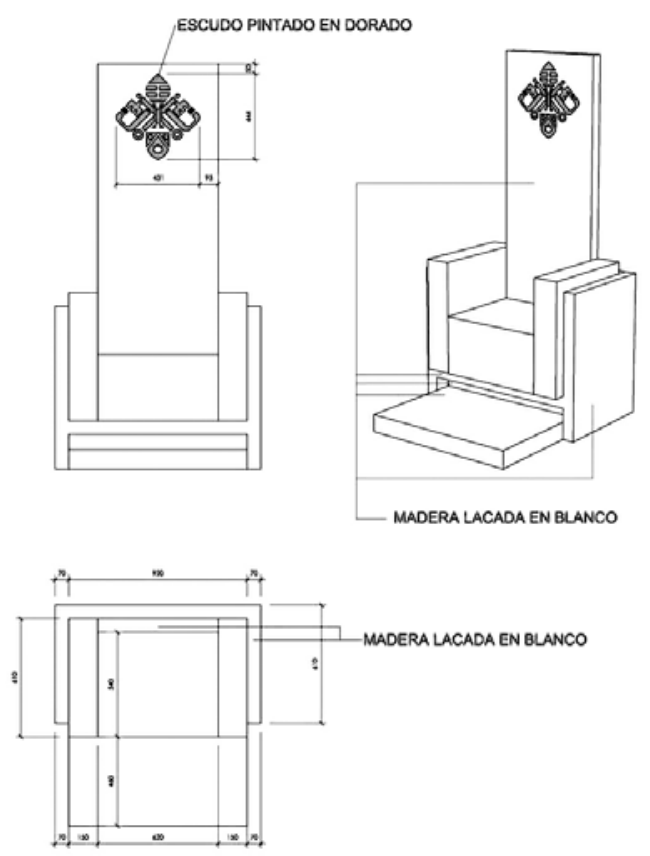


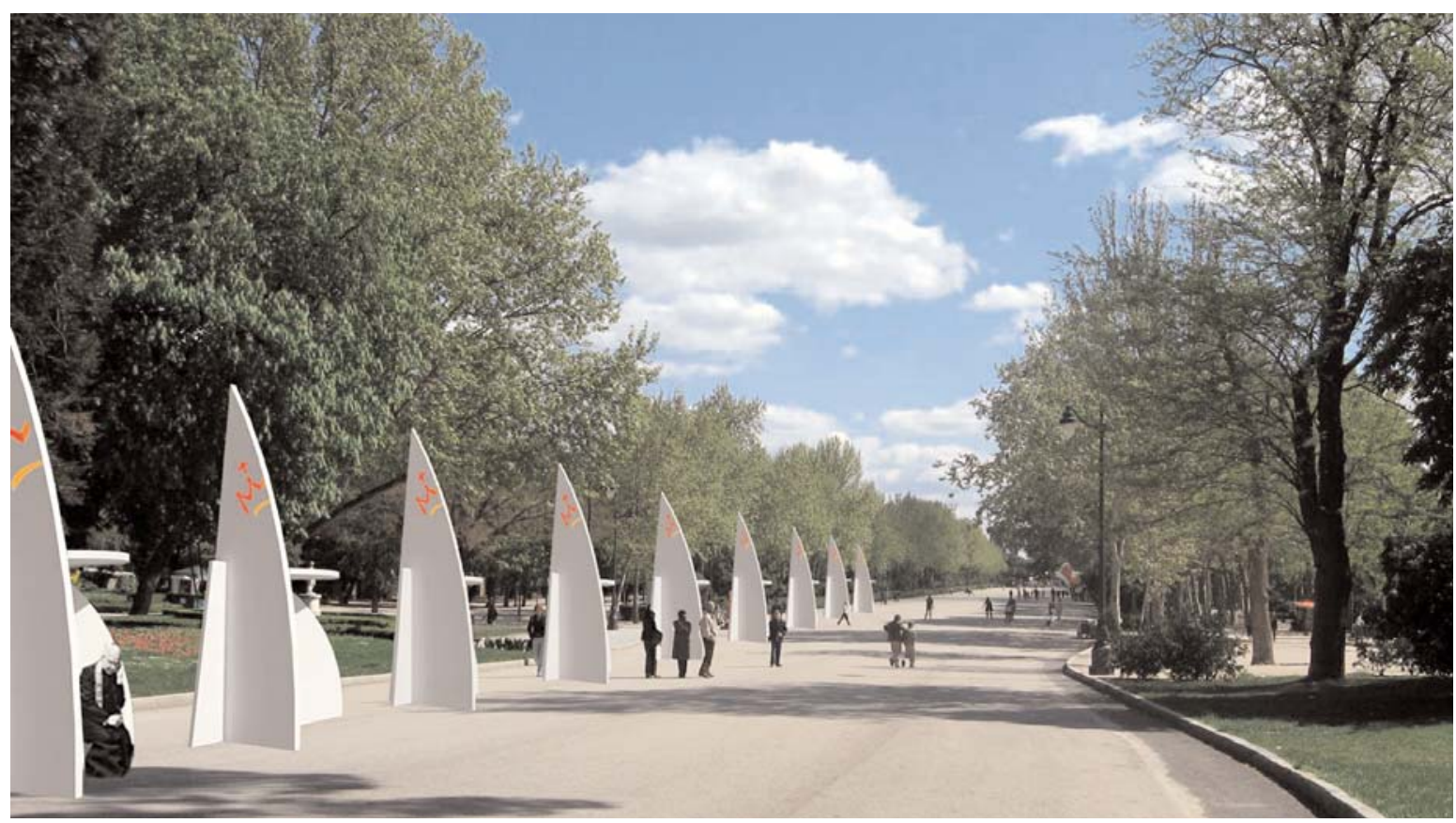

Fig. 07. Vicens+Ramos, Parque del perdón en los Jardines del Buen Retiro; proyecto. Fig. 08. Maqueta del confesionario desmontable.
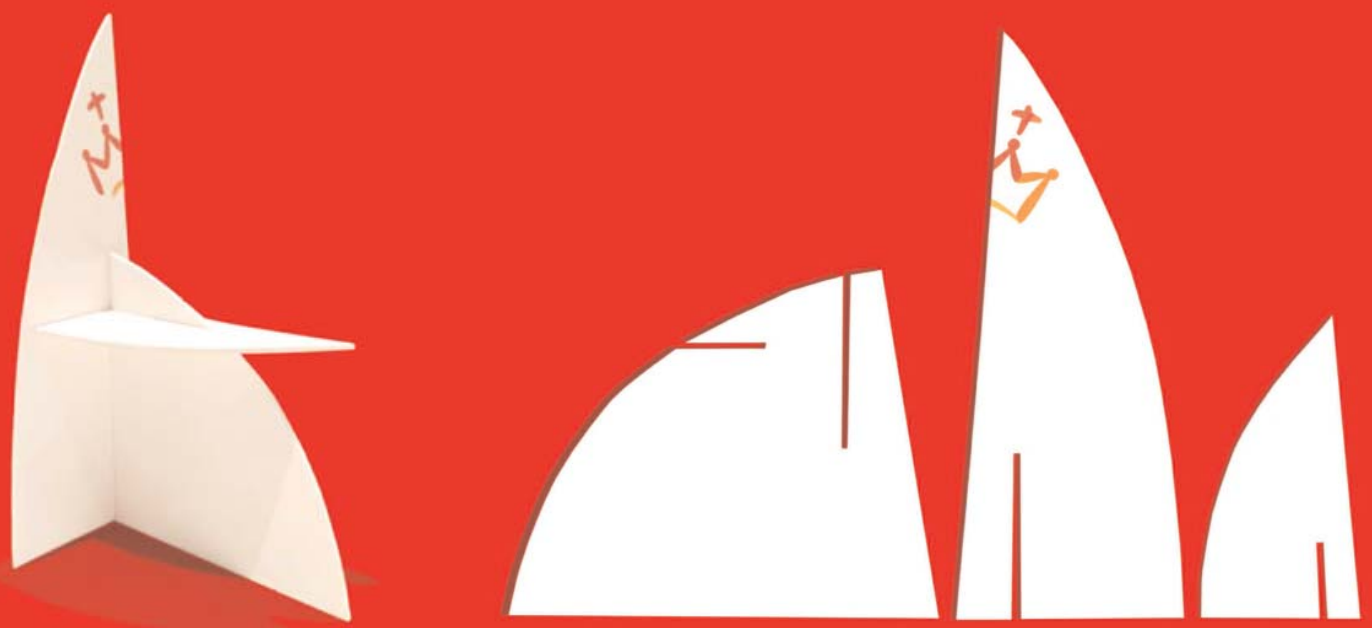

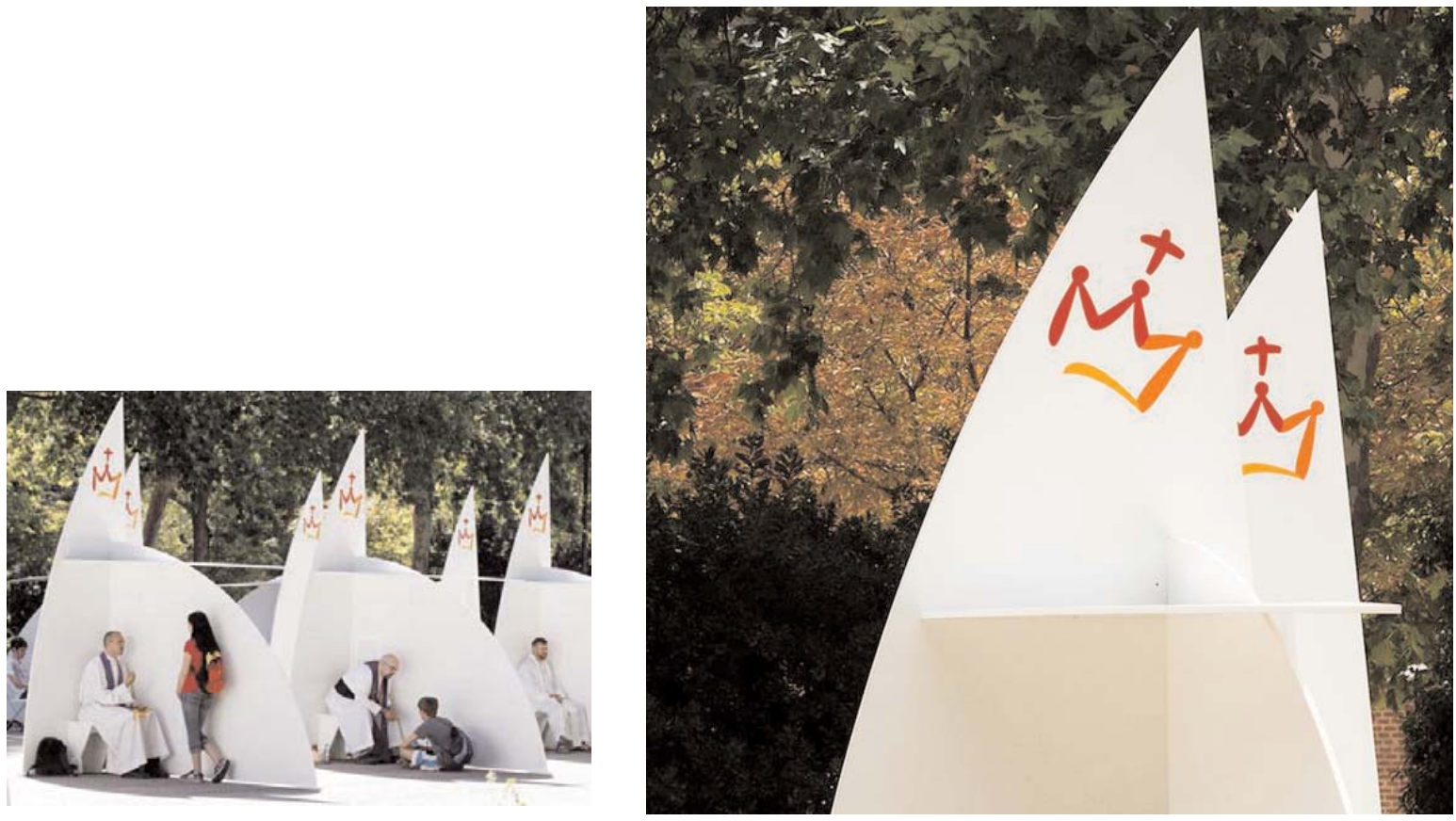

Fig. 09-11. Los confesionarios en funcionamiento.
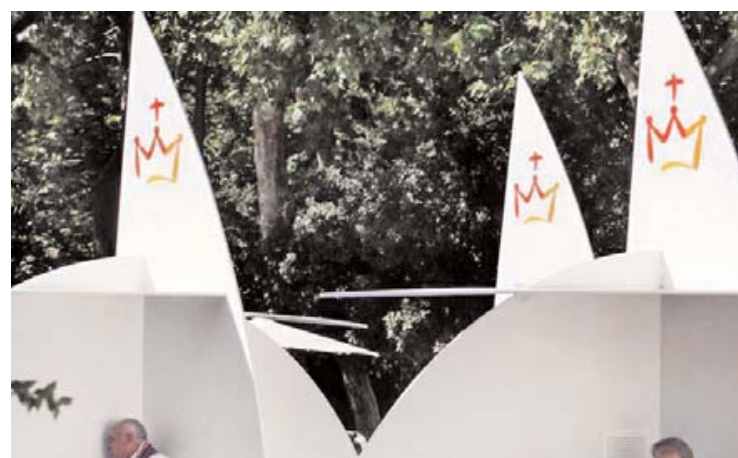


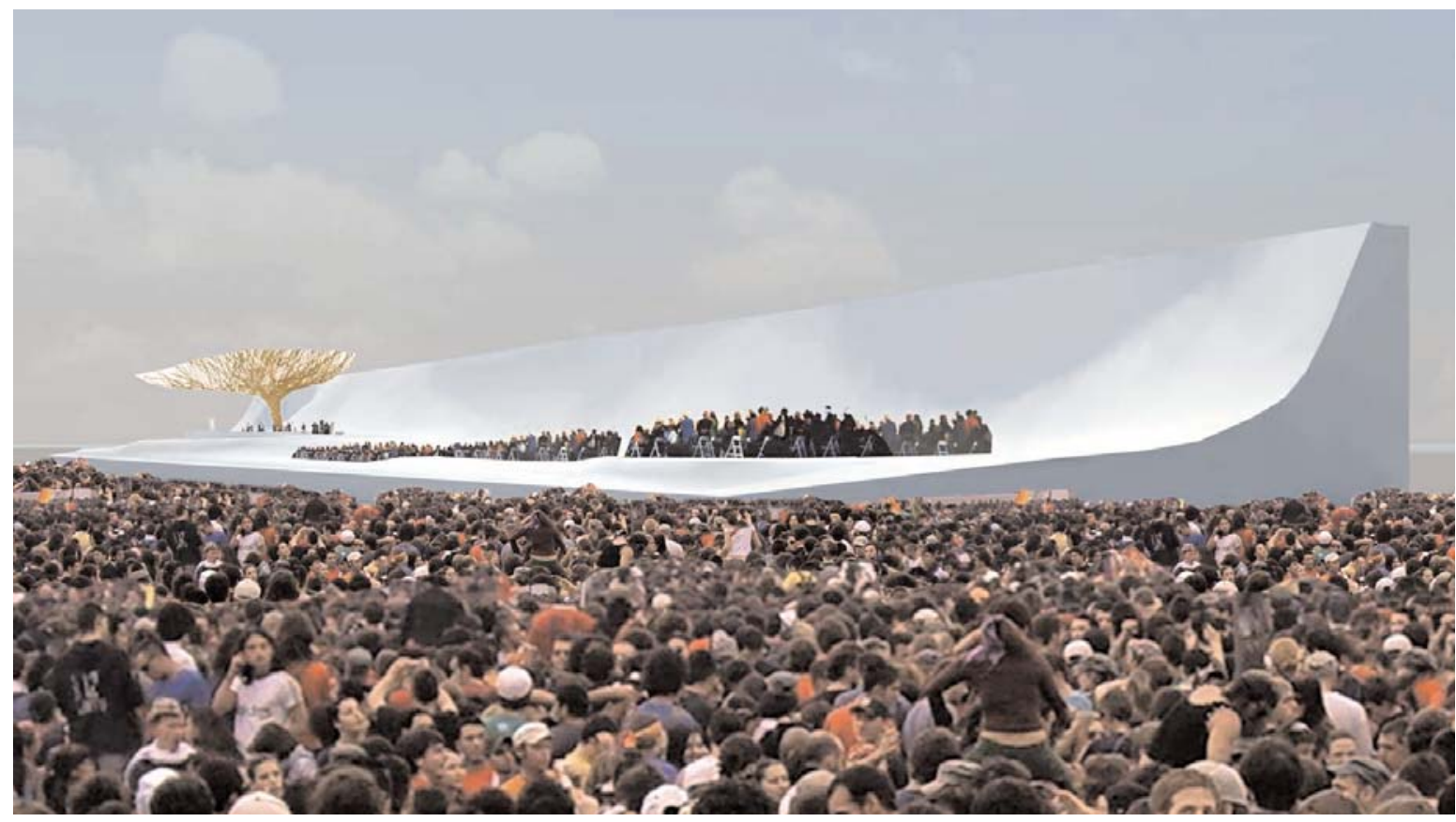

Fig. 12. Vicens+Ramos, Estrado base para la JMJ en la base aérea de Cuatro Vientos; vista diurna de la propuesta. Fig. 13. Vicens+Ramos, Plan general de ordenación del conjunto.

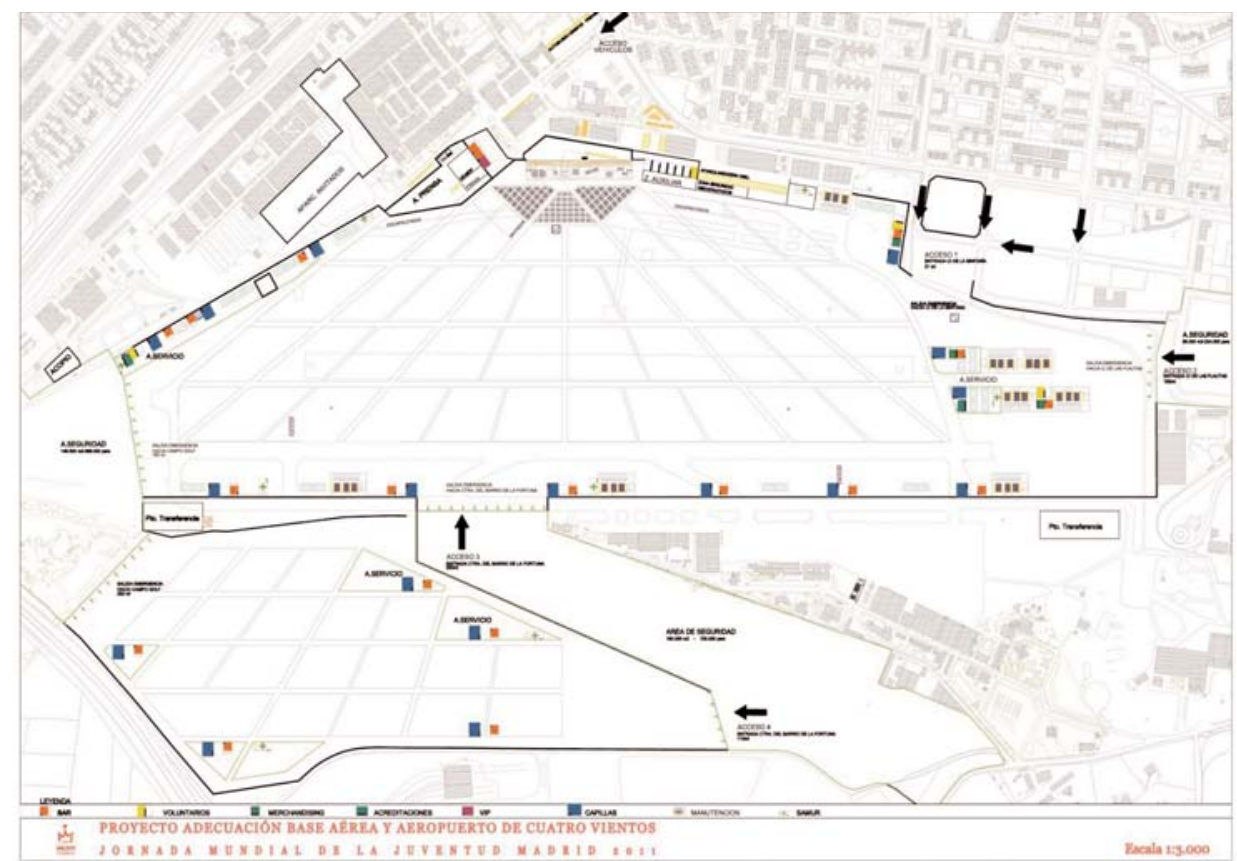




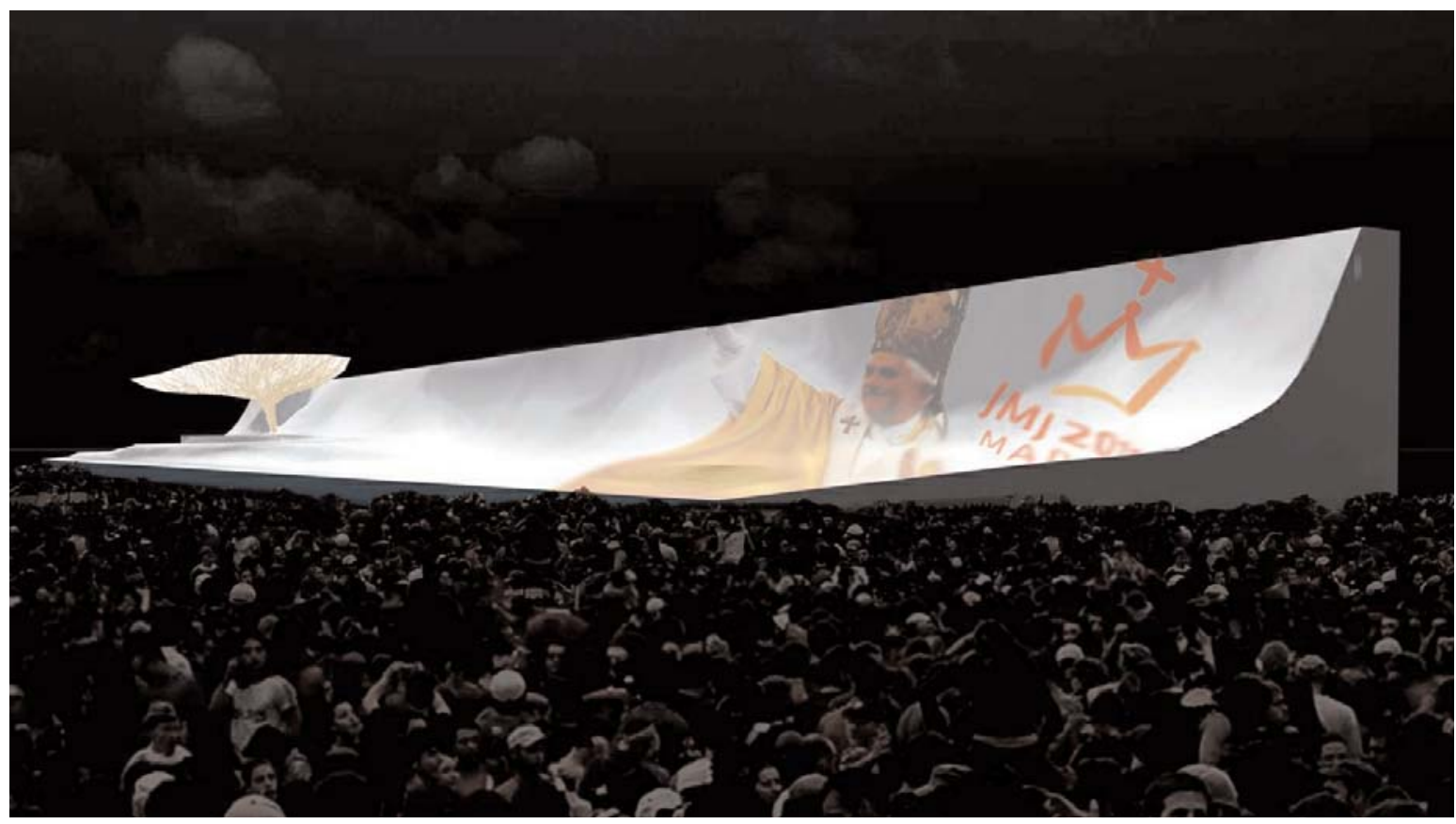

Fig. 14. Estrado base para la JMJ en la base aérea de Cuatro Vientos; vista nocturna de la propuesta. Fig. 15. Ignacio Vicens, boceto del estrado.

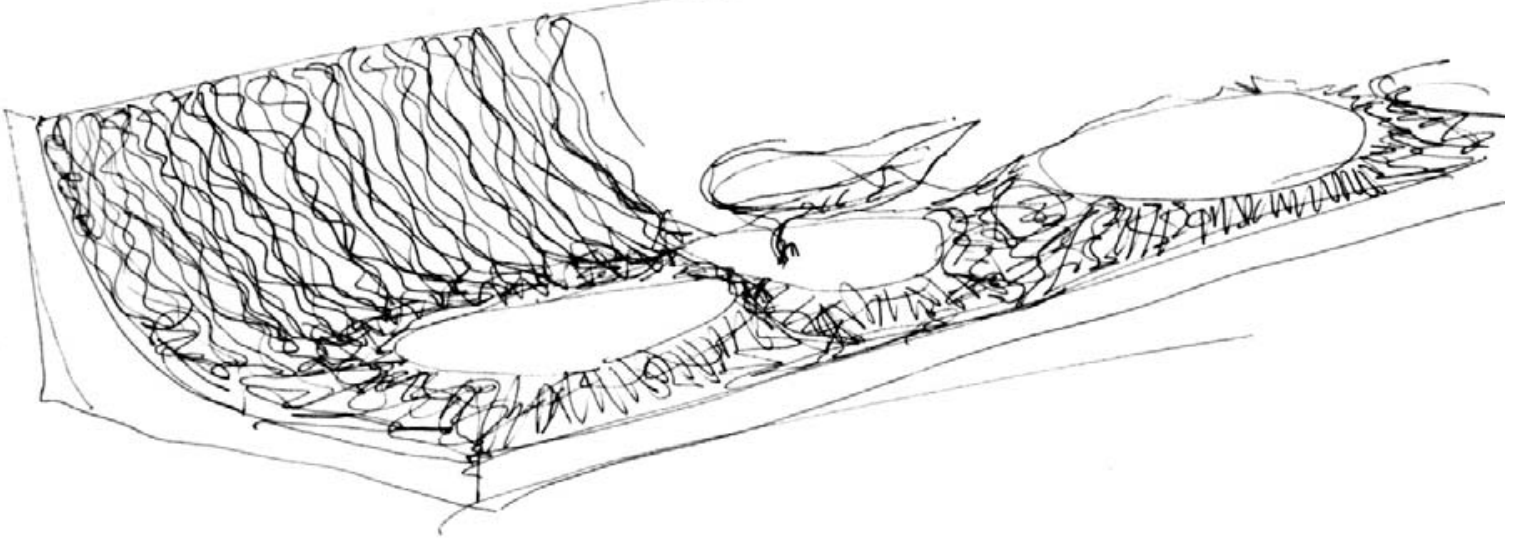




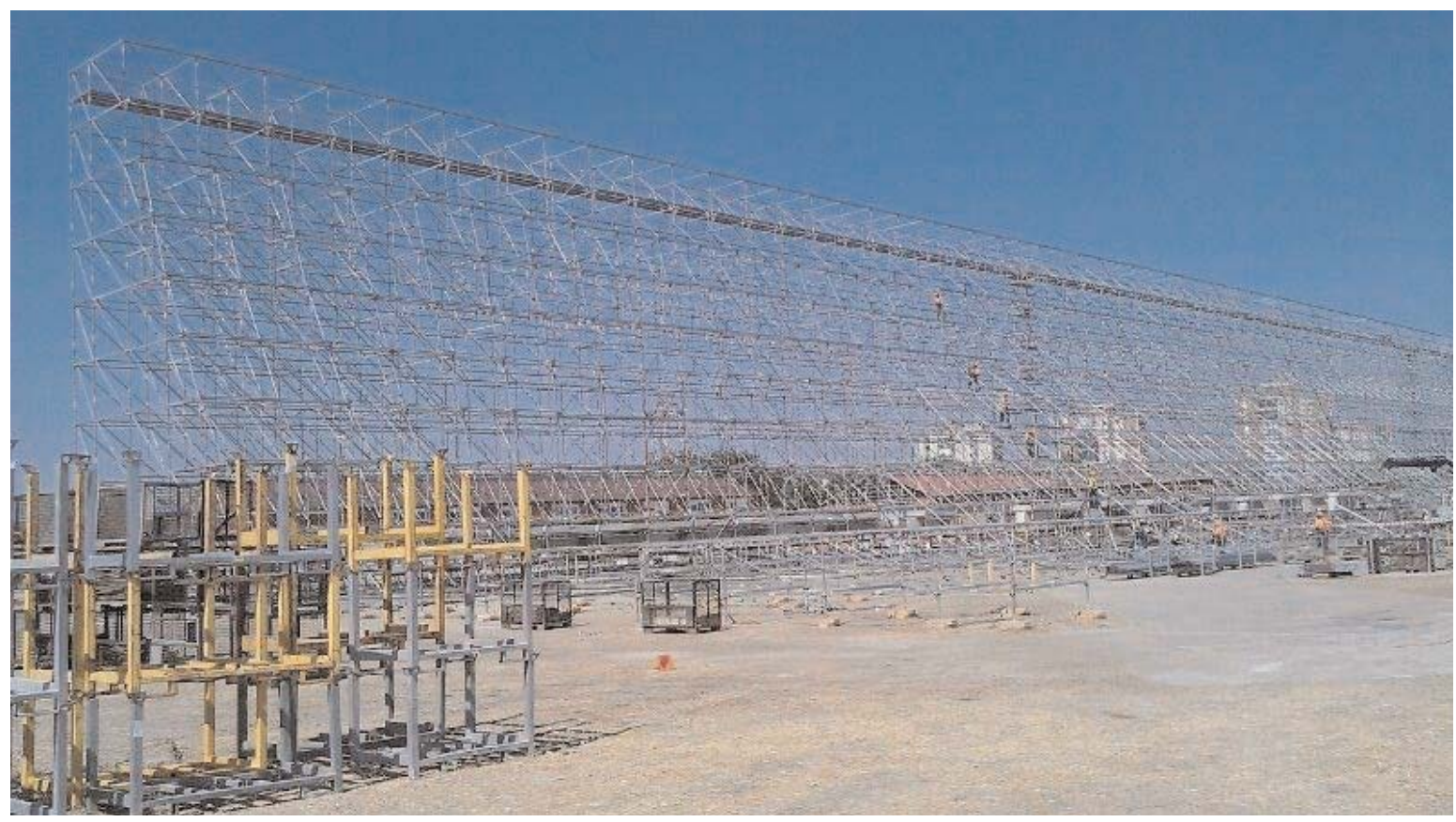

Fig. 16. Estructura del estrado realizada con mecanotubo.

Fig. 17. Proceso de recubrimiento del estrado con telas recicladas y tablero contrachapado.

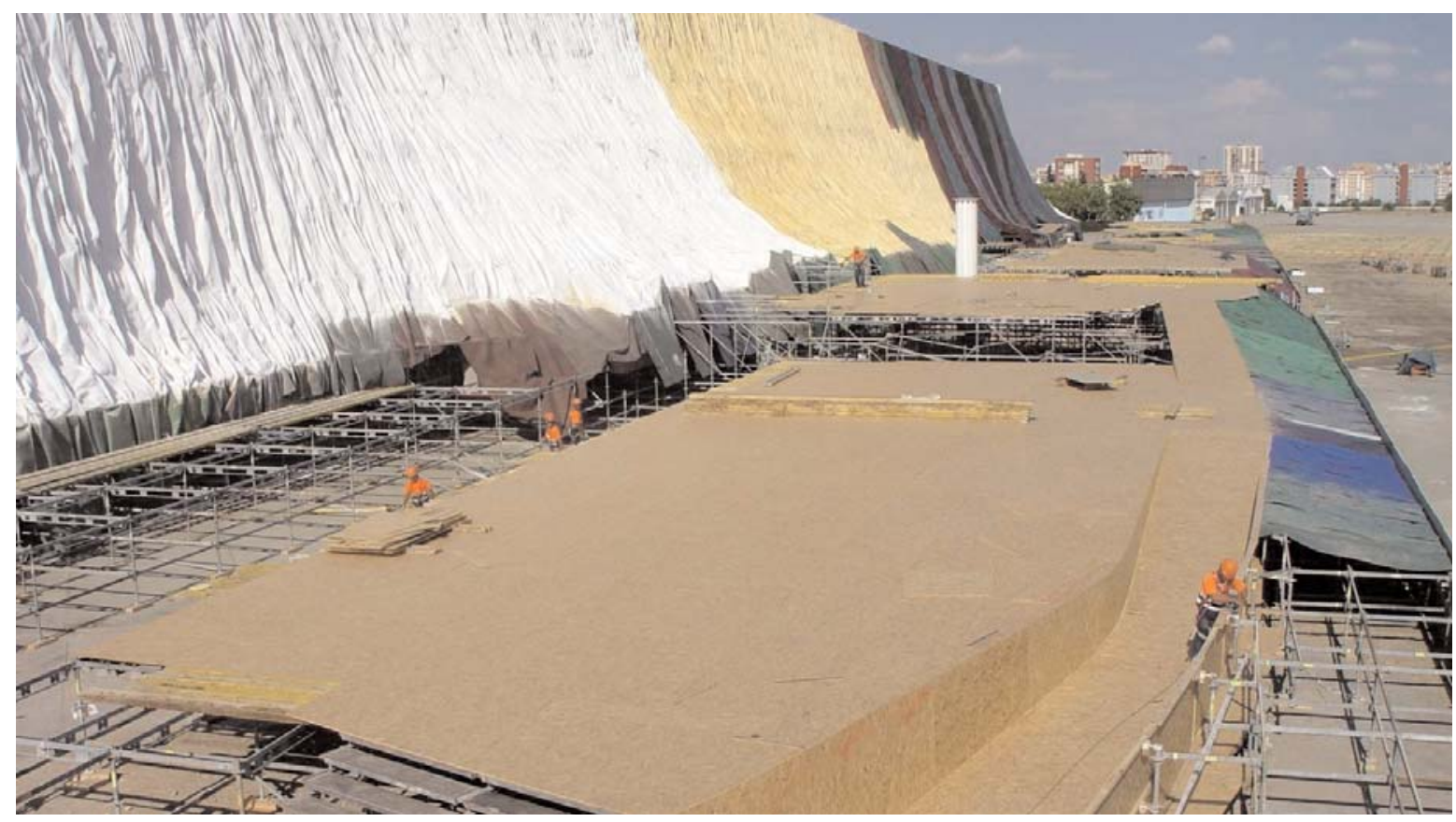




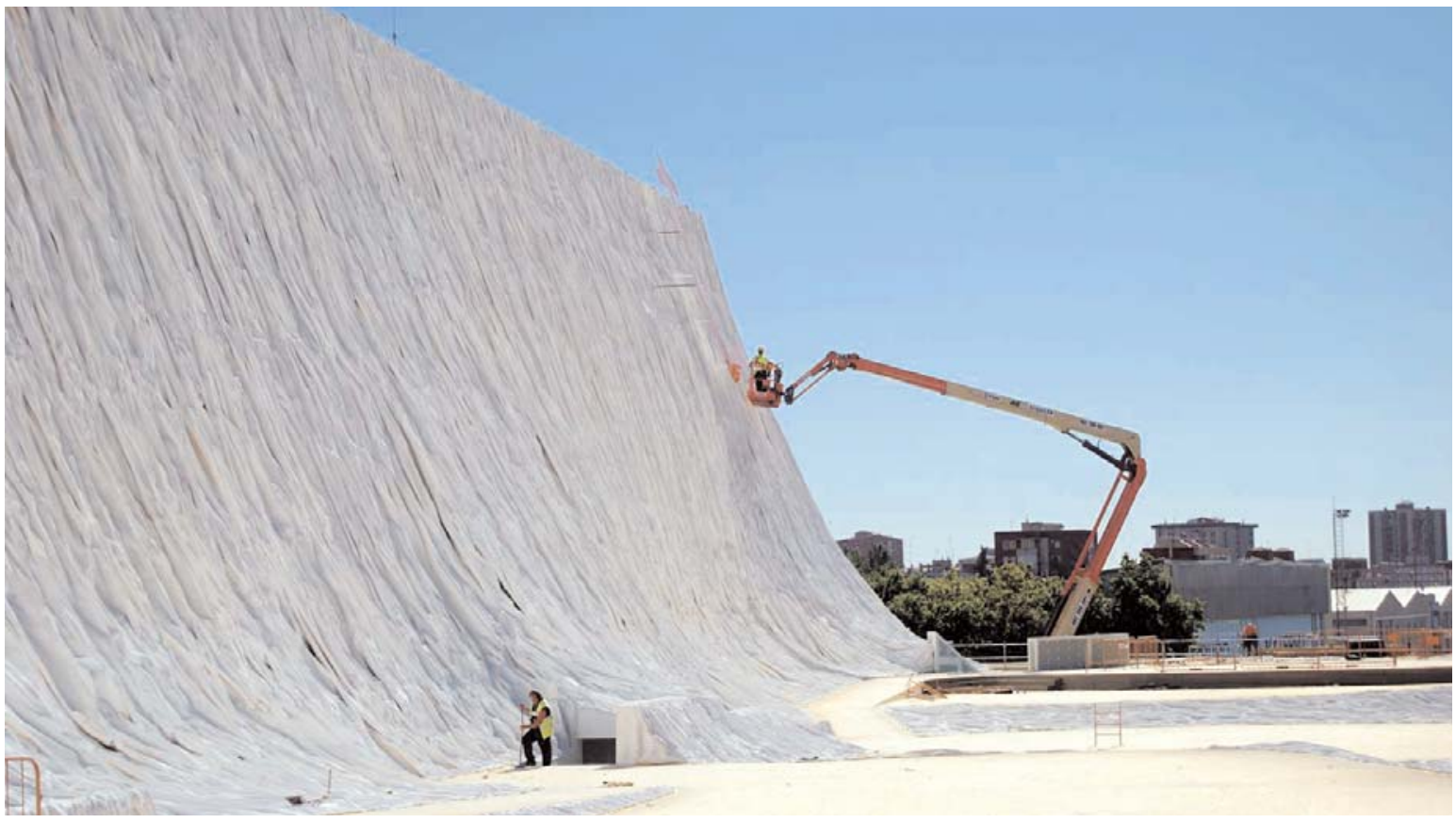

Fig. 18. Pintado de las telas recicladas.

Fig. 19. Izado y colocación de la estructura arborescente retroiluminada.

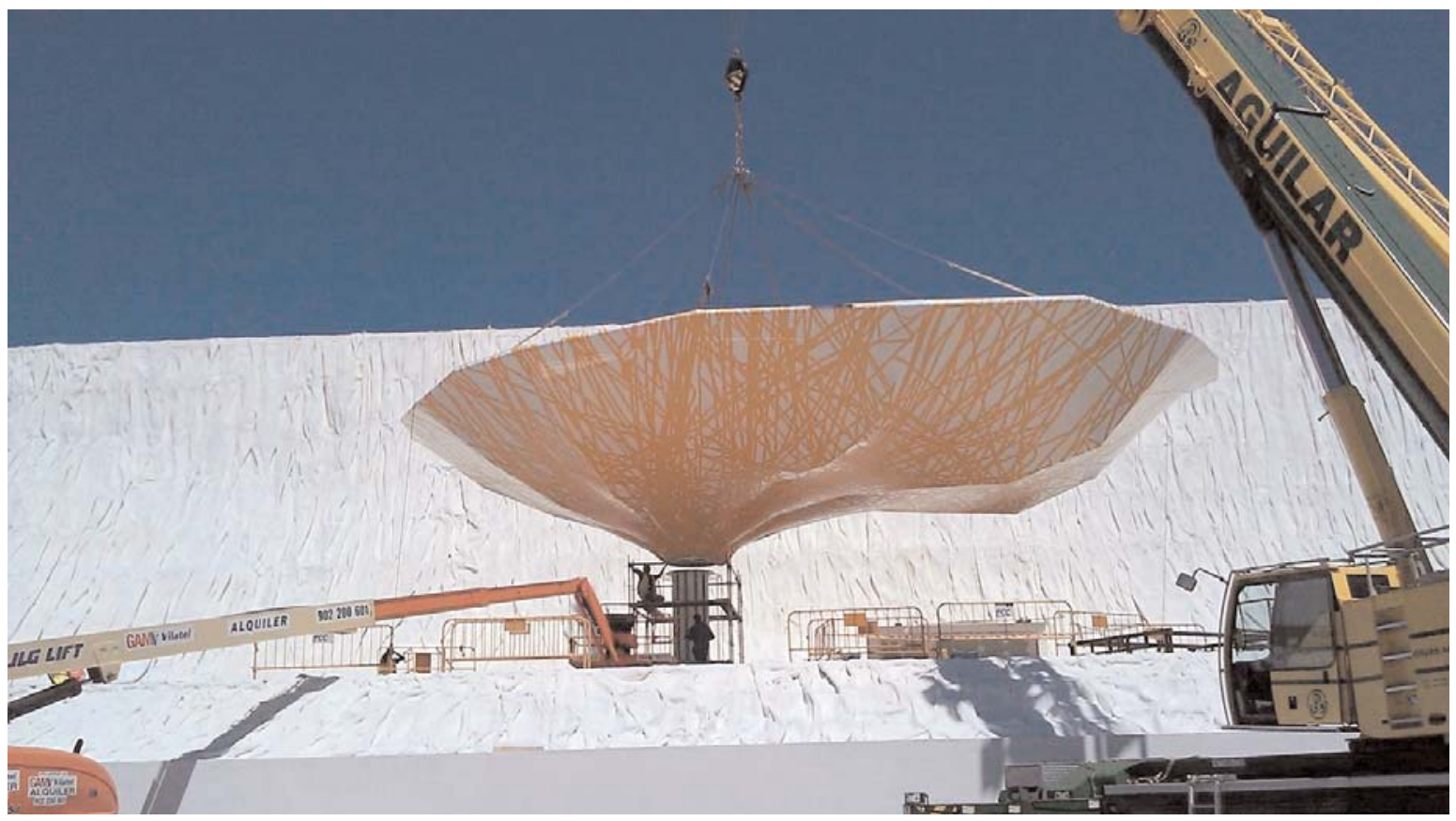




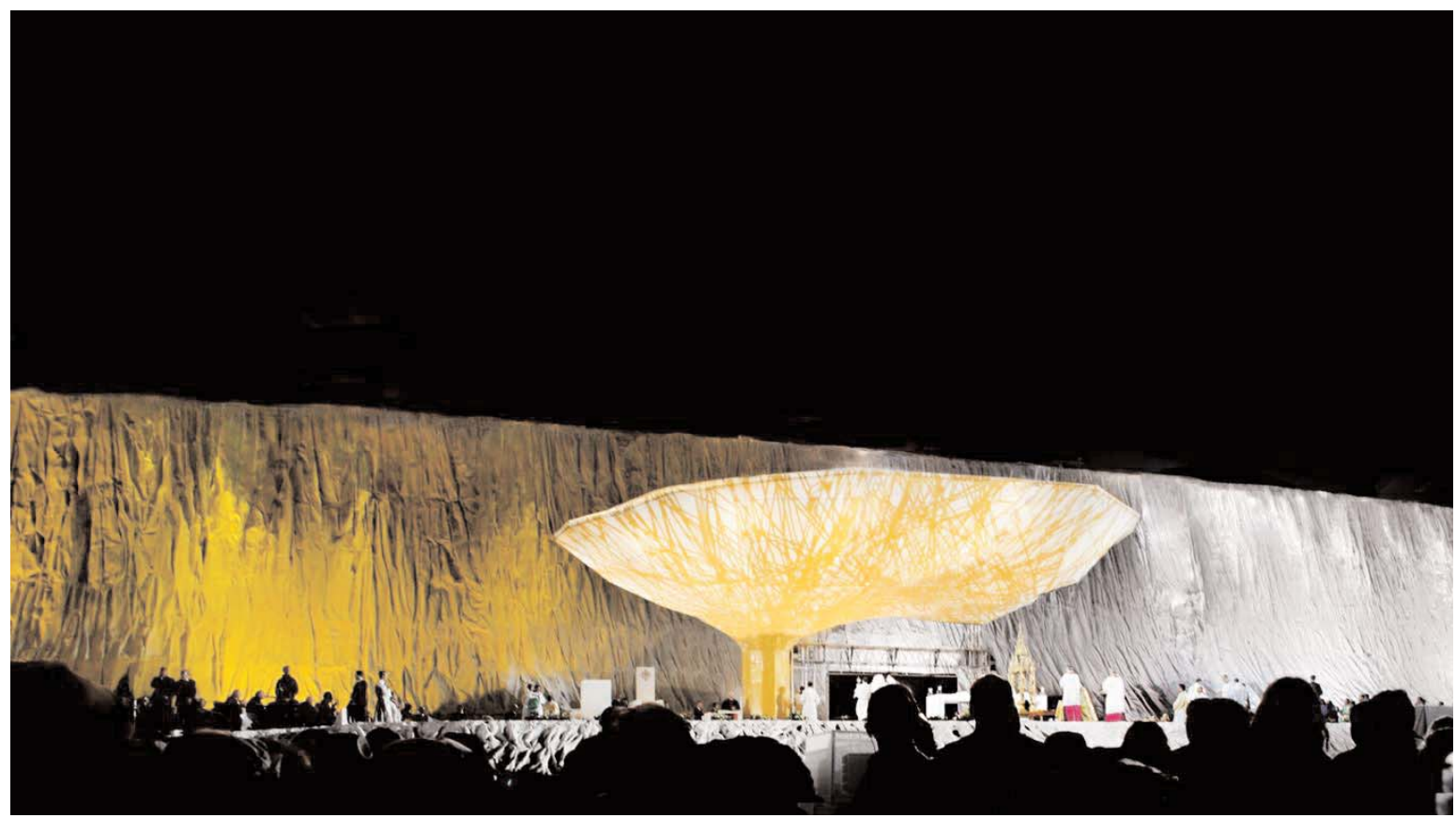

Fig. 20. Vista del estrado durante la vigilia de oración. Fig. 21. Planta de ocupación del estrado.

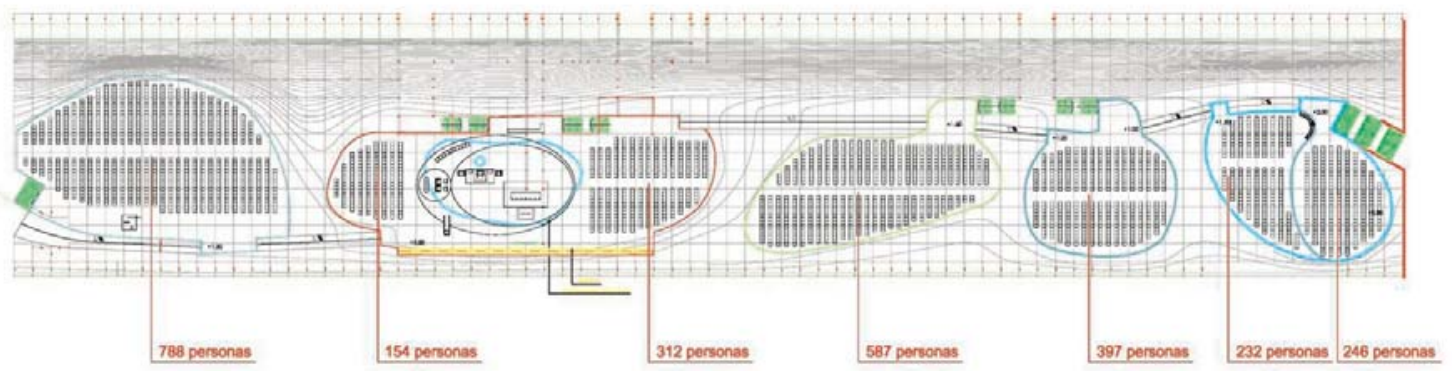

Ocupecion total: 2716 personas

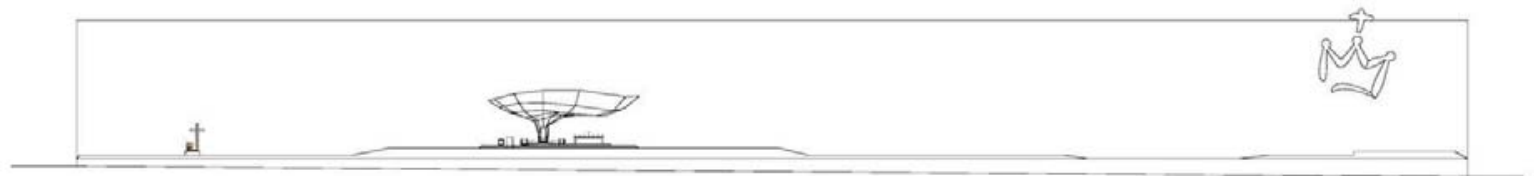




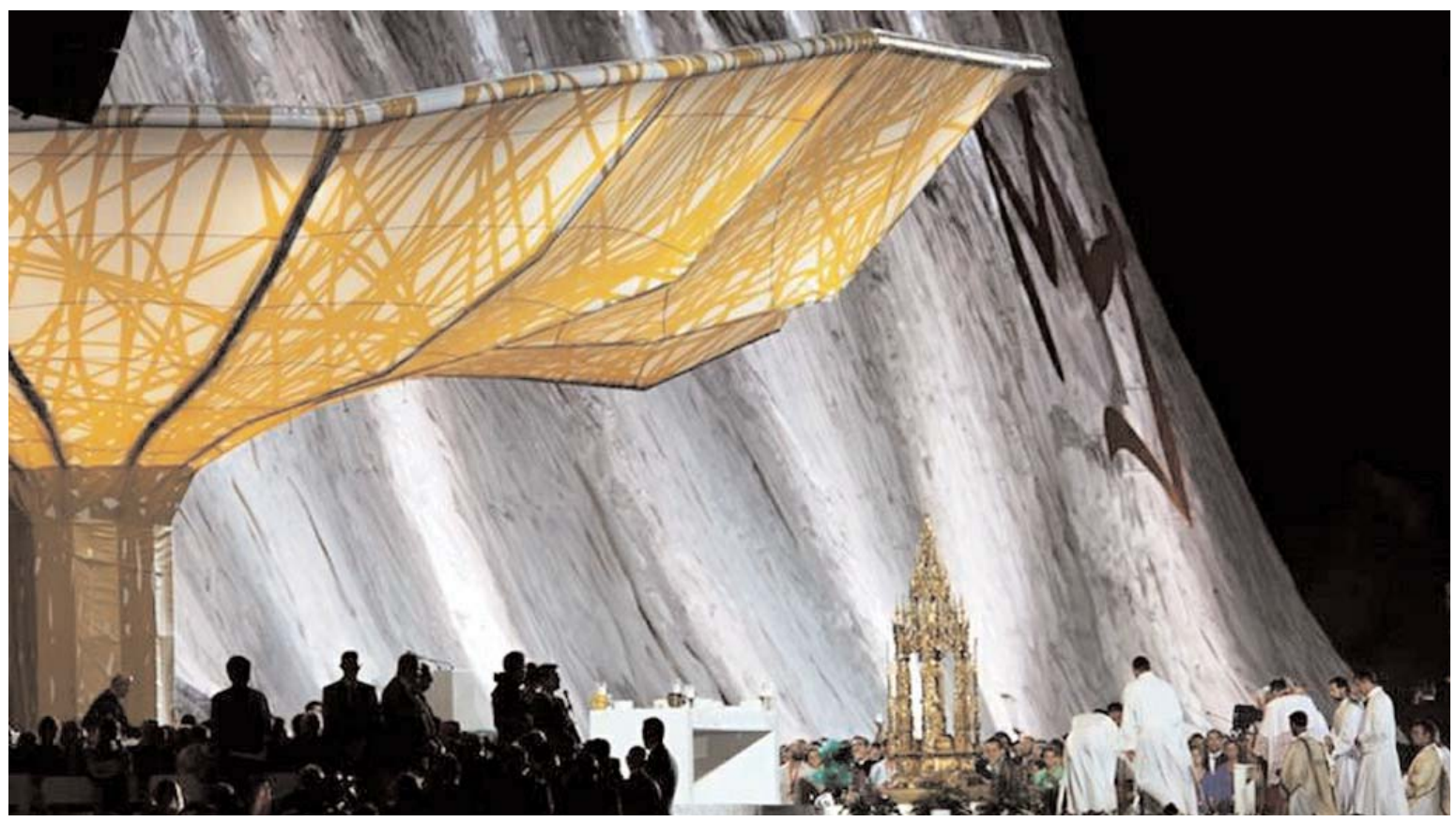

Fig. 22. La estructura arborescente retroiluminada durante la adoración eucarística. Fig. 23. El Santo Padre Benedicto XVI imparte la bendición desde el estrado.

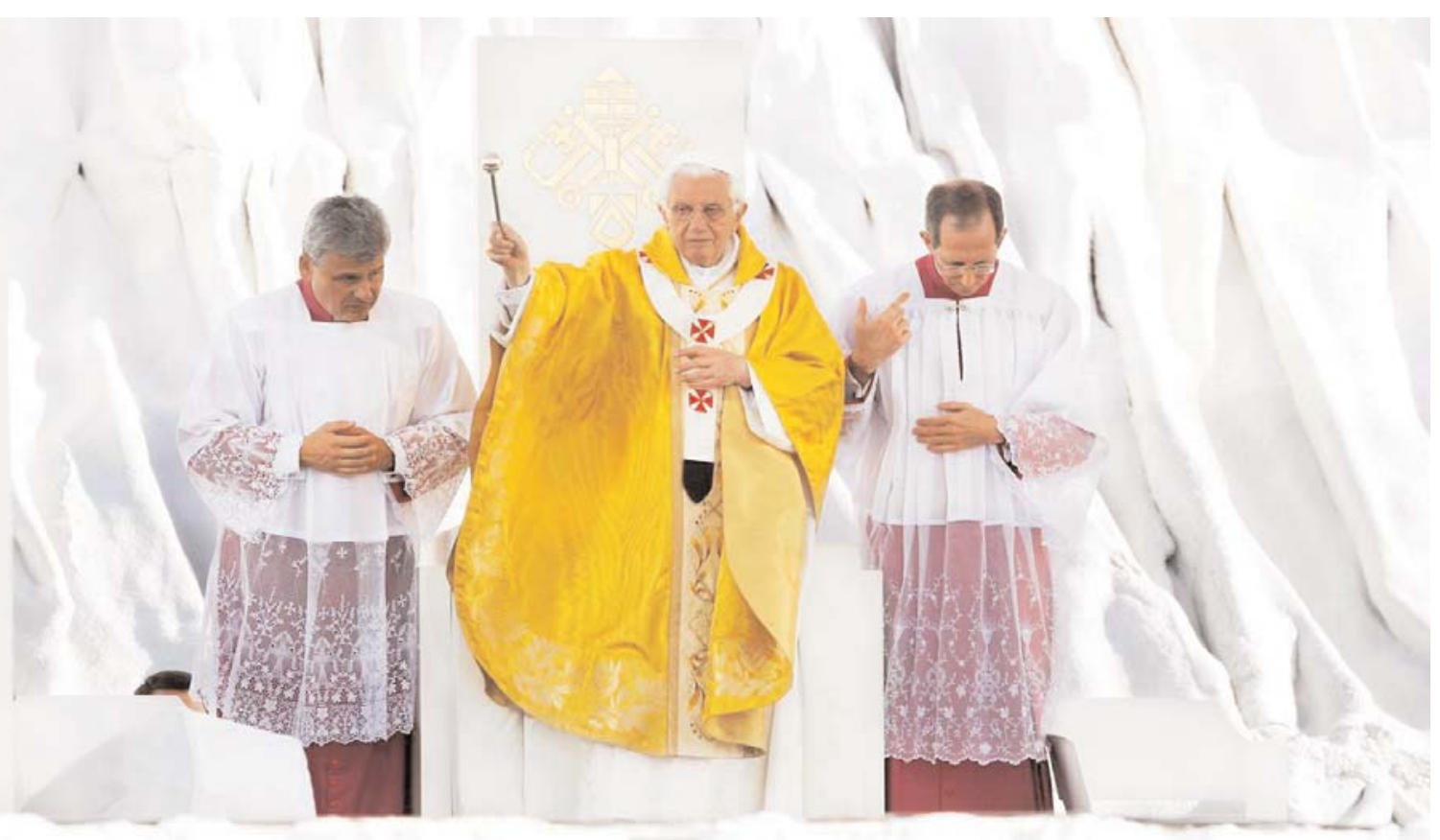




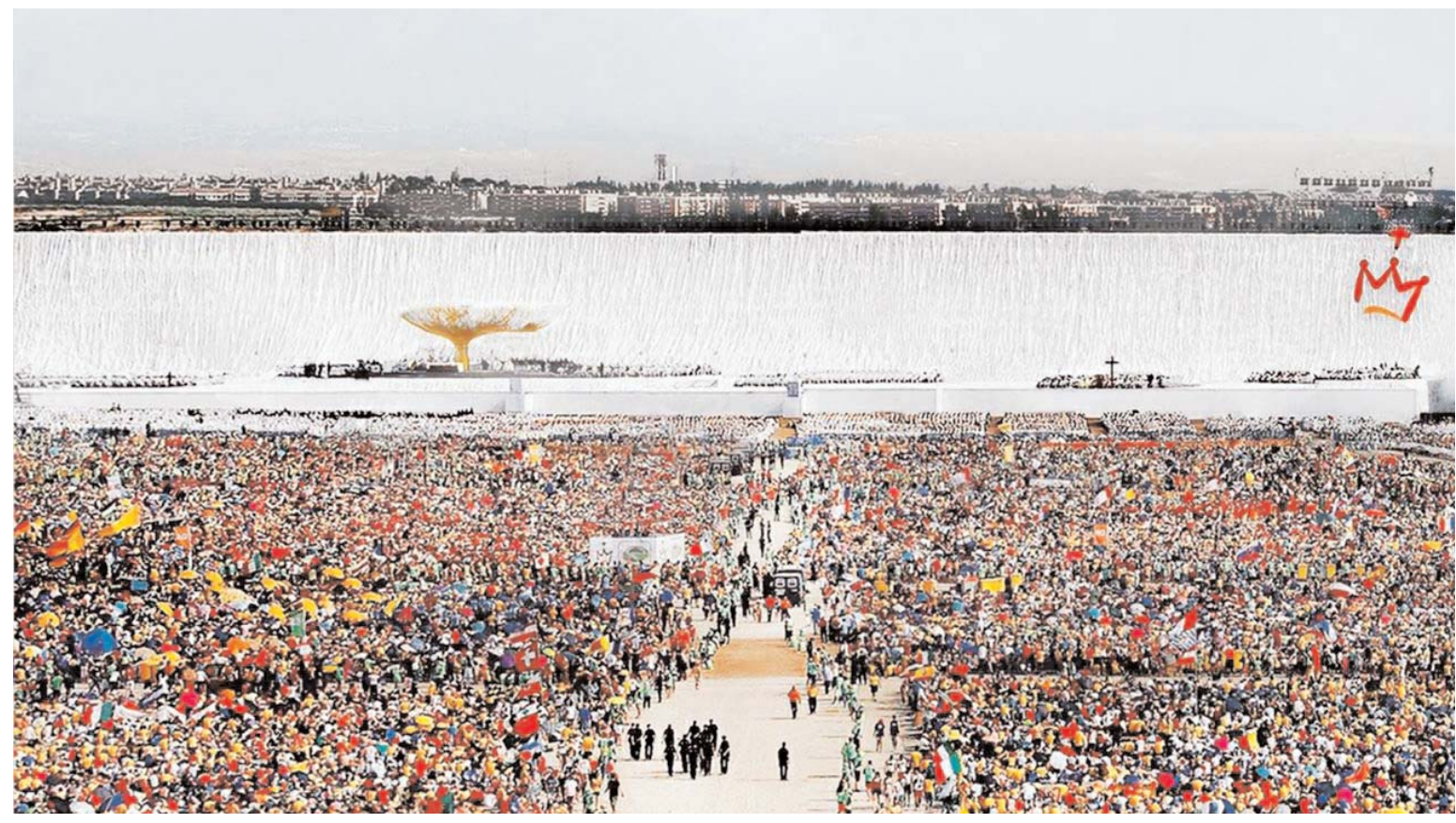

Fig. 24. Vista general del estrado durante la celebración eucarística de clausura.

Fig. 25. Ignacio Vicens (der.) con Victoriano Sainz, Sevilla 2013. 
EQUIPAMIENTOS LITÚRGICOS AL AIRE LIBRE PARA LA JORNADA MUNDIAL DE LA JUVENTUD MADRID 2011

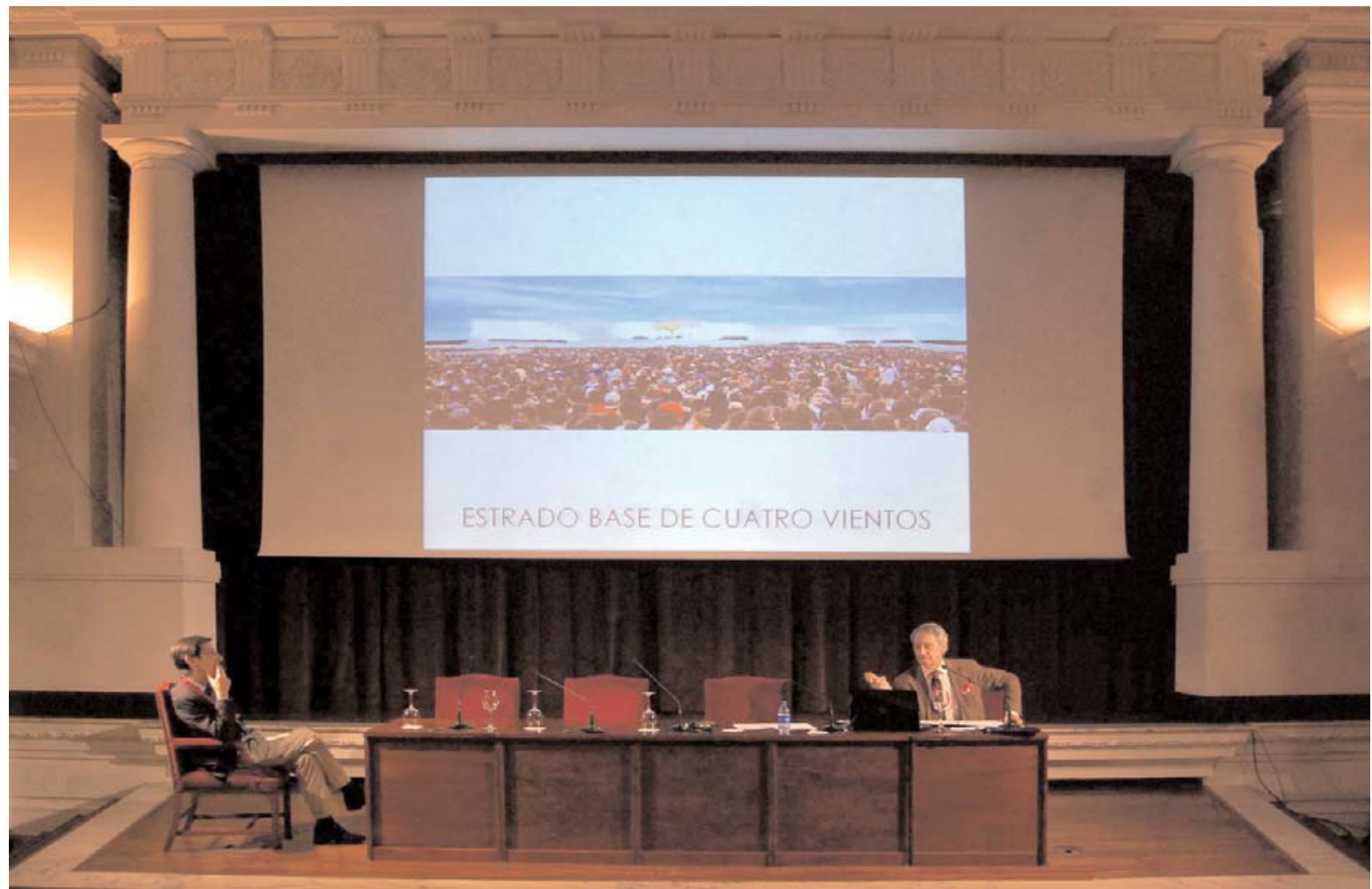

